純 粹大氣 の 摷 散 $几$ 就 て* 川畑幸夫, ${ }^{* *}$ 川崎 弘***

（1）緒 言 視程の問題に關しては純粹大氣の推散度を瑟め波長別に知り置くことが大事であ ると思はれる，元來日射に對する地球大氣の透過率始ち換言すれば地球大氣に因る日射の減害は主 として次の原因に基く.

\title{
（1）純粹乾燥大氣的の空楊分子因る控散
}

(口) 大氣中の水蒸氣化因 万擴散

（八）大氯中の瓦斯體（主として水蒸氣）因る吸收

（二）大氧中に浮游せる暨埃粒子に因方擴散之收吸

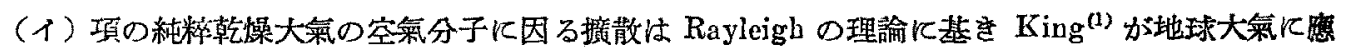
し用そ處で，其の理論は蜜測值とも極めてよく一致することは，齊しく認められて居る處である。 空氣清澄にして，塺埃の影響を殆んど受けず，及上空の水蒸氣に因る日射減衰に對する補正も相當

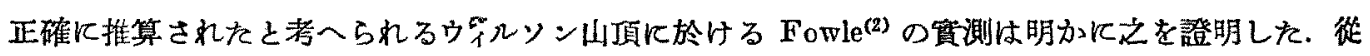
つて日射の觀測成績を整理するに賞つては，先つ此の純粹乾燥大氮の空氣分子Kよる摭散を計算し

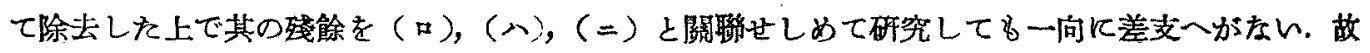
に本報文に於ては先づそれを波長別に精しく調へ，更に波長について積分し，全日射に對する透過 率を（空氣分子の撰散どけを考へて）求める. 斯くして得られた結果を利用して熱帶地方々溫帶地

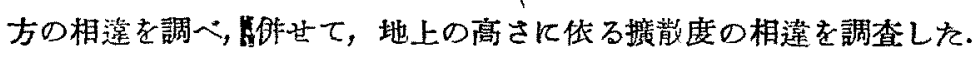

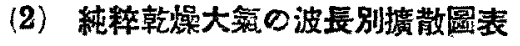

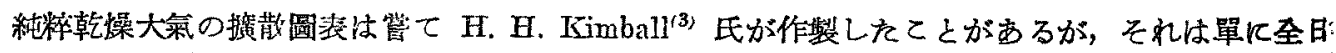

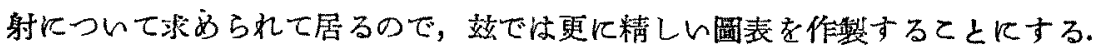

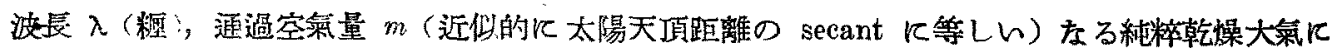

* Y. Kawabata and H. Kawasaki : A Computation of Molecular Scattering of the Earth's Atmosptere.

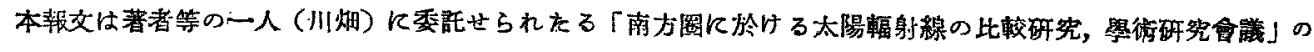
道程中の一部をなる゙のである。

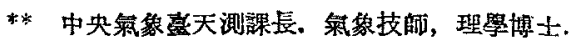

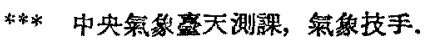

(1) Phil. Trans. Roy. Eoc., A. 212 (1913).

(2) A. J., 38 (1913).

(3) H. H. Kimball: Measurements of Solar Radiation Intensity etc, Month. Weath. Rev. (1927). 
對する日射の透過率を， $a_{a \lambda}{ }^{n \downarrow}$ ，で表せば，King ${ }^{1)}$ K低り $a_{a \lambda}$ は

$$
a_{a \lambda}=e^{-k} \quad k=\frac{32}{3}\left[\pi^{3}(n b-1)^{2} \frac{H}{N_{0} \lambda^{4}}+b H\right] \frac{P}{P_{0}}+D
$$

となる，但し政に

$n=$ 客氣の屈折率, $n-1) 10^{7}=2875.16+\frac{13.412}{\lambda^{2}} 10^{-8}+\frac{0.3777}{\lambda^{4}} 10^{-16}$,

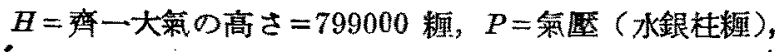

$N_{0}=1$ 立方糎中に含まれる分子数 $\left(P_{0}=76\right.$ 粝, $\left.t=0^{\circ} \mathrm{C}\right)=2.705 \times 10^{19}$,

$b=$ 永久瓦斯化つて熱へ變成されて任舞ふエネルギー,

$D=$ 糜块に依る娍衰項(波長には大して閵係がない).

假定化依り，純粹空策分子のみを考入るのであるから先づ $b=D=0$ 之置き，透過率 $a_{a \lambda}$ を計算し，通 過空棦量或注太陽高度を橫軸にとり波長をパラメーターとしてそれを圖示すれば第1圖の如くなる.

純粹大氧の分子擴散だけを考入るならば，通過空氣量の

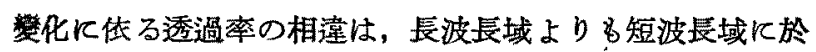

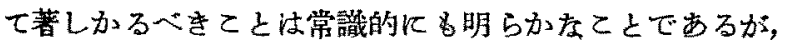
それが圖如䨢に示されて居る. 例一壮赤外日射 $\lambda=$ $7000 \AA$ であると，太陽が天頂にあるとき約 $97 \%$ 透過し， 太陽汃地平線附近にあつても（通過空氣量 8 は太陽高度約 $7^{\circ}$ K當る) $75 \%$ 以上透過するが，例一ば紫外線 $\lambda=3000 \AA$

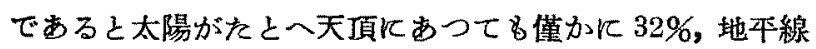
附近では $0 \%$ 郎ち擴散されて殆んど地表には到達しない。 又赤外域に於ては透過萃江通過空氣量に殆んど直線的に比 例して減少するが，波長が短くなる社ど最初天媔附近で急 激に減少し，後徐ミ減少する傾向がある.太陽が天頂に

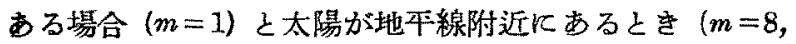

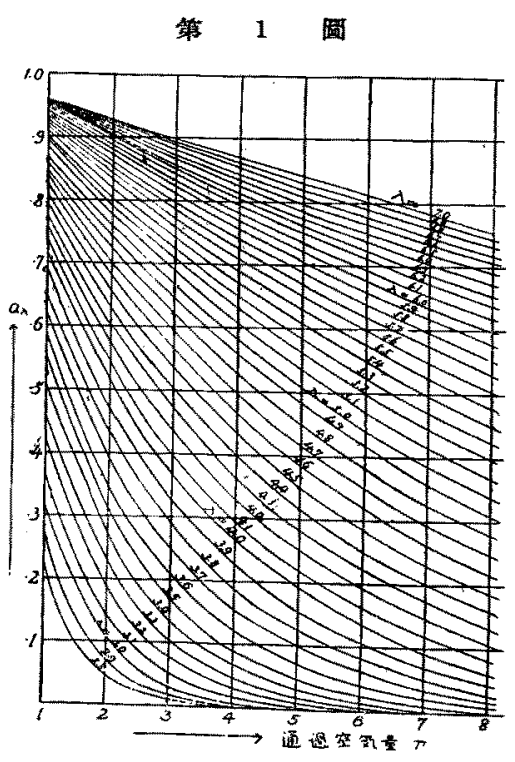
$\left.h=7^{\circ}\right)$ の場合の透過率の絕對值が最も著しく異るのは $\lambda=4000 \AA$ 附近であつて，此の波長附近は 大氣外日射のエネルギーが比較的大存ることを考入合せれば，上の事筫は重要な意義を存すると言 はねばをらぬ。

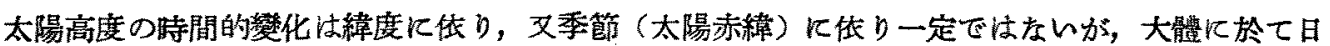

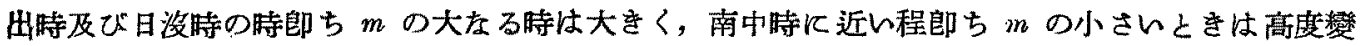

1) L. V. King: On the Scattering and Absorption of Light in Gaseous Media. etc. Phil. Trans. Rog. Soc. London, A 212, 375 *433. (1913). 


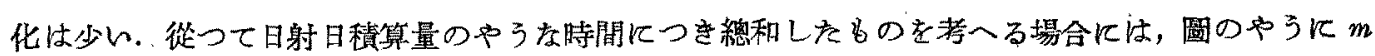

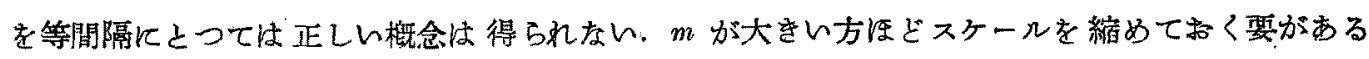
が，其の縮め方は緯度と季節によつて一樣でないから，假に太陽高度を一樣飞横軸にとつて調にてて

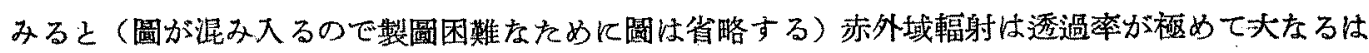

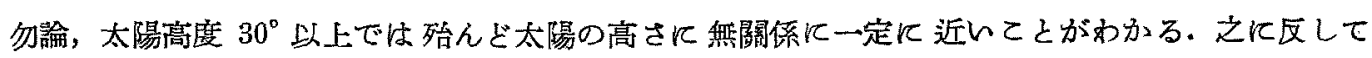
紫外線になるえ太陽高度 $60^{\circ}$ 以下で既に透過率は著しく減少する。此のことは地表面上に於ける

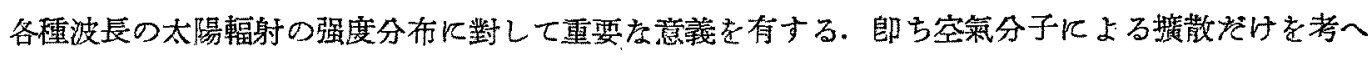
るならば，長波長輻射注主として可照時だけで定まるが，紫外域日射は可照時の他に太陽高度に著 しく左右せられ，たと一可照時が同一であつても，太陽高度の變化する有樣によつて著しい相違が

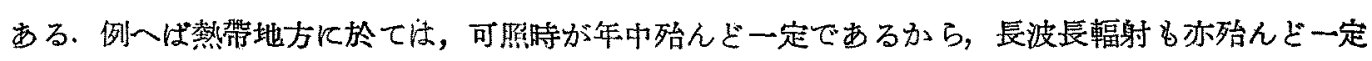
であるが，それ拘らず紫外線量は多少年變化をなすてとが推察される. 文溫帶寒帶地方でも， 長波長輻射汢大體可照時に比例して增減するが，紫外線量は其の他飞太陽高度の變化の影響が加は るので更に啫しい年變化をするてとになる。

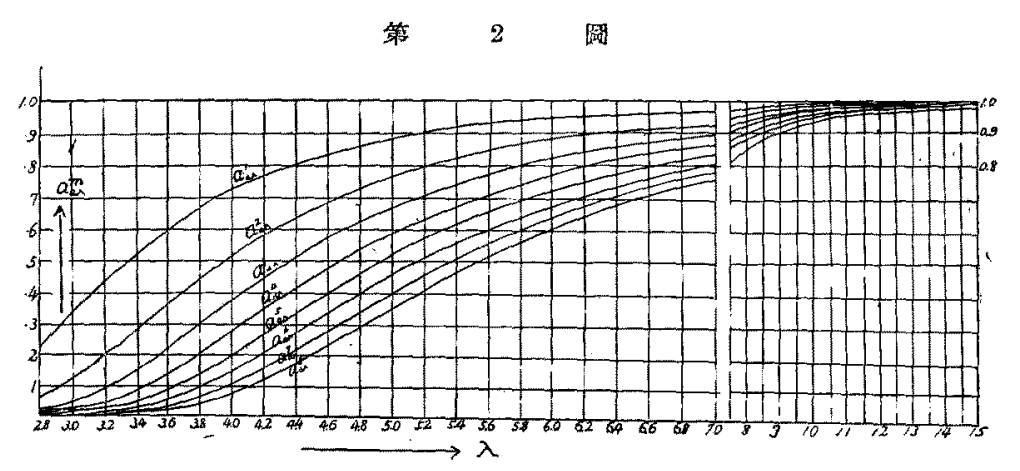

同じととであるが，通過空氣量をパラメーターとして輻射線の波長と透過率 $a_{a \lambda}{ }^{m}$ を $m=1,2, \cdots$

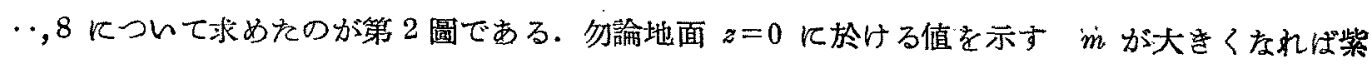
外線は殆んど地面をでは到達しないで，散媲されて虚空八援がつて仕舞ふが，長波長となるに從ひ

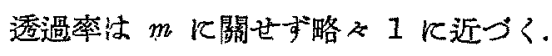

地上 $1 \mathrm{~km} \cdots 6 \mathrm{~km}$ に於ける $a a_{\lambda}{ }^{m}$ 女同樣にして求められる. 此の場合には前の $P=P_{0}=76$ 糎 の代りに實際に其の腐位の氣壓を用ひればよん。

\section{(3). 全日射に對する塘散圖表}

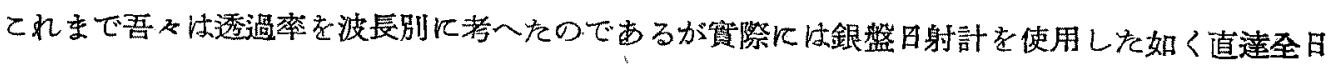
射として測定された場合が多い。

今大氣外日射を $I_{0 \lambda}$ とすれば筫際地面で觀測さるべき日射量 $I_{m \lambda}$ は純粹大氧に對して沈 


\begin{tabular}{|c|c|c|c|c|c|c|c|c|}
\hline$\lambda$ in $\mathrm{c}$ & $\mathrm{crn}$ & $\underset{a_{a \lambda}}{0 \mathrm{~km}}$ & $\underset{a_{a \lambda}}{1 \mathrm{~km}}$ & $2 \mathrm{~km}$ & $\underset{a_{a \lambda}}{3 \mathrm{~km}}$ & $\underset{a a \lambda}{4 \mathrm{~km}}$ & $\begin{array}{c}5 \mathrm{~km} \\
a_{a \lambda}\end{array}$ & $\begin{array}{c}6 \mathrm{~km} \\
a_{a \lambda}\end{array}$ \\
\hline $\begin{array}{l}2.8 \times 10 \\
2.9\end{array}$ & $10^{-5}$ & $\begin{array}{l}0.215 \\
0.267\end{array}$ & $\begin{array}{l}0.261 \\
0.315\end{array}$ & $\begin{array}{l}0.316 \\
0.372\end{array}$ & $\begin{array}{l}0.383 \\
0.439\end{array}$ & $\begin{array}{l}0.464 \\
0.518\end{array}$ & $\begin{array}{l}0.564 \\
0.611\end{array}$ & $\begin{array}{l}0.682 \\
0.720\end{array}$ \\
\hline $\begin{array}{l}3.0 " \prime \\
3.1 " \\
3.2 " \\
3.3 \\
3.4 " \\
3.5 "\end{array}$ & & $\begin{array}{l}0.321 \\
0.372 \\
0.422 \\
0.469 \\
0.513 \\
0.554\end{array}$ & $\begin{array}{l}0.370 \\
0.421 \\
0470 \\
0.516 \\
0.558 \\
0.597\end{array}$ & $\begin{array}{l}0.426 \\
0.477 \\
0.524 \\
0.567 \\
0.607 \\
0.642\end{array}$ & $\begin{array}{l}0.491 \\
0.539 \\
0.583 \\
0.623 \\
0.659 \\
0.692\end{array}$ & $\begin{array}{l}0.567 \\
0.611 \\
0.650 \\
0.686 \\
0.717 \\
0.745\end{array}$ & $\begin{array}{l}0.653 \\
0.691 \\
0.724 \\
0.754 \\
0.779 \\
0.802\end{array}$ & $\begin{array}{l}0.753 \\
0.782 \\
0.807 \\
0.828 \\
0.847 \\
0.863\end{array}$ \\
\hline $\begin{array}{l}3.6 " 1 " \\
3.7 \\
3.8 " \\
3.9 " \\
4.0 "\end{array}$ & $\begin{array}{l}y \\
y \\
y \\
y \\
y\end{array}$ & $\begin{array}{l}0.592 \\
0.627 \\
0.658 \\
0.689 \\
0.714\end{array}$ & $\begin{array}{l}0.632 \\
0.664 \\
0.694 \\
0.703 \\
0.744\end{array}$ & $\begin{array}{l}0.675 \\
0.704 \\
0.731 \\
0.740 \\
0.776\end{array}$ & $\begin{array}{r}0.721 \\
0.747 \\
0.770 \\
-0.778 \\
0.810\end{array}$ & $\begin{array}{l}0.770 \\
0.792 \\
0.812 \\
0.818 \\
0.845\end{array}$ & $\begin{array}{l}0.822 \\
0.840 \\
0.855 \\
0.860 \\
0.881\end{array}$ & $\begin{array}{l}0.877 \\
0.890 \\
0.901 \\
0.905 \\
0.919\end{array}$ \\
\hline $\begin{array}{l}4.1 " \\
4.2 \\
4.3 \\
4.4 \\
4.5\end{array}$ & "y & $\begin{array}{l}0.737 \\
0.759 \\
0.779 \\
0.796 \\
0.813\end{array}$ & $\begin{array}{l}0.766 \\
0.786 \\
0.803 \\
0.819 \\
0.834\end{array}$ & $\begin{array}{l}0.796 \\
0.813 \\
0.829 \\
0.843 \\
0.856\end{array}$ & $\begin{array}{l}0.827 \\
0.842 \\
0.855 \\
0.867 \\
0.878\end{array}$ & $\begin{array}{l}0.859 \\
0.871 \\
0.883 \\
0.893 \\
0.902\end{array}$ & $\begin{array}{l}0.892 \\
0.902 \\
0.911 \\
0.918 \\
0.925\end{array}$ & $\begin{array}{l}0.927 \\
0.934 \\
0.940 \\
0.945 \\
0.950\end{array}$ \\
\hline $\begin{array}{l}4.6 \\
4.7 \\
4.8 \\
4.9 \\
5.0\end{array}$ & 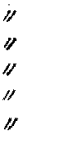 & $\begin{array}{l}0.827 \\
0.841 \\
0.853 \\
0.864 \\
0.874\end{array}$ & $\begin{array}{l}0.847 \\
0.859 \\
0.870 \\
0.880 \\
0.889\end{array}$ & $\begin{array}{l}0.867 \\
0.878 \\
0.887 \\
0.896 \\
0.904\end{array}$ & $\begin{array}{l}0.888 \\
0.897 \\
0.905 \\
0.913 \\
0.919\end{array}$ & $\begin{array}{l}0.909 \\
0.917 \\
0.924 \\
0.930 \\
0.935\end{array}$ & $\begin{array}{l}0.932 \\
0.937 \\
0.842 \\
0.947 \\
0.951\end{array}$ & $\begin{array}{l}0.954 \\
0.958 \\
0.961 \\
0.964 \\
0.967\end{array}$ \\
\hline $\begin{array}{l}5.1 " \\
5.2 \\
5.3 " \\
5.4 \\
5.5\end{array}$ & 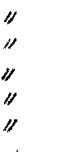 & $\begin{array}{l}0.883 \\
0.892 \\
0.899 \\
0.906 \\
0.913\end{array}$ & $\begin{array}{l}0.897 \\
0.904 \\
0.911 \\
0.918 \\
0.923\end{array}$ & $\begin{array}{l}0.911 \\
0.918 \\
0.923 \\
\times 0.929 \\
0.934\end{array}$ & $\begin{array}{l}0.925 \\
0.931 \\
0.936 \\
0.940 \\
0.945\end{array}$ & $\begin{array}{l}0.940 \\
0.944 \\
0.848 \\
0.952 \\
0.955\end{array}$ & $\begin{array}{l}0.955 \\
0.958 \\
0.961 \\
0.964 \\
0.966\end{array}$ & $\begin{array}{l}0.970 \\
0.972 \\
0.974 \\
0.976 \\
0.978\end{array}$ \\
\hline $\begin{array}{l}5.6 \\
5.7 \\
5.8 \\
5.9 \\
6.0\end{array}$ & " & $\begin{array}{l}0.919 \\
0.924 \\
0.929 \\
0.934 \\
0.938\end{array}$ & $\begin{array}{l}0.929 \\
0.933 \\
0.947 \\
0.942 \\
0.945\end{array}$ & $\begin{array}{l}0.938 \\
0.943 \\
0.946 \\
0.950 \\
0.953\end{array}$ & $\begin{array}{l}0.948 \\
0.952 \\
0.955 \\
0.958 \\
0.961\end{array}$ & $\begin{array}{l}0.959 \\
0.961 \\
0.964 \\
0.966 \\
0.969\end{array}$ & $\begin{array}{l}0.969 \\
0.971 \\
0.973 \\
0.975 \\
0.976\end{array}$ & $\begin{array}{l}0.979 \\
0.980 \\
0.982 \\
0.983 \\
0.984\end{array}$ \\
\hline $\begin{array}{l}6.1 \\
6.2 \\
6.3 \\
6.4 \\
6.5\end{array}$ & 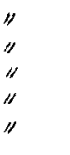 & $\begin{array}{l}0.942 \\
0.945 \\
0.949 \\
0.952 \\
0.955\end{array}$ & $\begin{array}{l}0.949 \\
0.952 \\
0.955 \\
0.958 \\
0.960\end{array}$ & $\begin{array}{r}0.956 \\
0.959 \\
0.961 \\
0.964 \\
0.966\end{array}$ & $\begin{array}{l}0.963 \\
0.966 \\
0.968 \\
0.970 \\
0.971\end{array}$ & $\begin{array}{l}0.970 \\
0.972 \\
0.974 \\
0.976 \\
0.977\end{array}$ & $\begin{array}{l}0.978 \\
0.979 \\
0.980 \\
0.982 \\
0.983\end{array}$ & $\begin{array}{l}0.985 \\
0.986 \\
0.987 \\
0.988 \\
0.989\end{array}$ \\
\hline $\begin{array}{l}6.6 \\
6.7 \\
6.8 \\
6.9 \\
7.0\end{array}$ & ", & $\begin{array}{l}0.957 \\
0.960 \\
0.962 \\
0.964 \\
0.966\end{array}$ & $\begin{array}{l}0.963 \\
0.965 \\
0.967 \\
0.969 \\
0.970\end{array}$ & $\begin{array}{l}0.968 \\
0.970 \\
0.971 \\
0.973 \\
0.975\end{array}$ & $\begin{array}{l}0.973 \\
0.980 \\
0.981 \\
0.982 \\
0.983\end{array}$ & $\begin{array}{l}0.978 \\
0.980 \\
0.981 \\
0.982 \\
0.983\end{array}$ & $\begin{array}{l}0.984 \\
0.985 \\
0.986 \\
0.986 \\
0.987\end{array}$ & $\begin{array}{l}0.989 \\
0.990 \\
0.990 \\
0.991 \\
0.991\end{array}$ \\
\hline $\begin{array}{r}7.5 \\
8.0 \\
8.5 \\
9.0 \\
9.5 \\
10.0\end{array}$ & 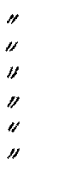 & $\begin{array}{l}0.974 \\
0.980 \\
0.986 \\
0.988 \\
0.990 \\
0.992\end{array}$ & $\begin{array}{l}0.978 \\
0.983 \\
0.988 \\
0.989 \\
0.992 \\
0.993\end{array}$ & $\begin{array}{l}0.981 \\
0.985 \\
0.990 \\
0.991 \\
0.991 \\
0.994\end{array}$ & $\begin{array}{l}0.987 \\
0.990 \\
0.993 \\
0.994 \\
0.995 \\
0.996\end{array}$ & $\begin{array}{l}0.987 \\
0.990 \\
0.993 \\
0.994 \\
0.995 \\
0.997\end{array}$ & $\begin{array}{l}0.990 \\
0.993 \\
0.995 \\
0.995 \\
0.596 \\
0.997\end{array}$ & $\begin{array}{l}0.994 \\
0.995 \\
0.997 \\
0.997 \\
0.998 \\
0.998\end{array}$ \\
\hline $\begin{array}{l}10.5 \\
11.0 \\
11.5 \\
12.0 \\
12.5 \\
13.0\end{array}$ & ", & $\begin{array}{l}0.993 \\
0.995 \\
0.995 \\
0.996 \\
0.997 \\
0.997\end{array}$ & $\begin{array}{l}0.994 \\
0.995 \\
0.996 \\
0.997 \\
0.997 \\
0.998\end{array}$ & $\begin{array}{r}0.995 \\
0.996 \\
0.997 \\
0.997 \\
.0 .998 \\
0.998\end{array}$ & $\begin{array}{l}0.997 \\
0.997 \\
0.998 \\
0.998 \\
0.998 \\
0.999\end{array}$ & $\begin{array}{l}0.997 \\
0.998 \\
0.998 \\
0.998 \\
0.998 \\
0.999\end{array}$ & $\begin{array}{l}0,998 \\
0.998 \\
0.998 \\
0.999 \\
0.999 \\
0.999\end{array}$ & $\begin{array}{l}0.998 \\
0.999 \\
0.999 \\
0.999 \\
0.999 \\
0.999\end{array}$ \\
\hline
\end{tabular}




\begin{tabular}{|c|c|c|c|c|c|c|c|}
\hline$\lambda$ in $\mathrm{cm}$ & $\begin{array}{c}0 \mathrm{~km} \\
a_{a \lambda}\end{array}$ & $\frac{1 \mathrm{~km}}{a_{a \lambda}}$ & $\begin{array}{c}2 \mathrm{~km} \\
a_{a \lambda}\end{array}$ & $\begin{array}{c}3 \mathrm{~km} \\
a_{a x}\end{array}$ & $\begin{array}{c}4 \mathrm{~km} \\
a_{a \lambda}\end{array}$ & $\underset{a a_{\lambda}}{5 \mathrm{~km}}$ & $\begin{array}{c}6 \mathrm{~km} \\
a a \lambda\end{array}$ \\
\hline $\begin{array}{l}13.5 \times 10^{-5} \\
14.0 " / \\
14.5 \% \\
15.0 "\end{array}$ & $\begin{array}{l}0.998 \\
0.998 \\
0.998 \\
0.998\end{array}$ & $\begin{array}{l}0.998 \\
0.998 \\
0.998 \\
0.999\end{array}$ & $\begin{array}{l}0.998 \\
0.999 \\
0.999 \\
0.999\end{array}$ & $\begin{array}{l}0.999^{-} \\
0.999 \\
0.999 \\
0.999^{\prime}\end{array}$ & $\begin{array}{l}0.999 \\
0.999 \\
0.999 \\
0.999\end{array}$ & $\begin{array}{l}0.999 \\
0.999 \\
0.999 \\
0.999\end{array}$ & $\begin{array}{l}0.999 \\
1.000 \\
1.000 \\
1.000\end{array}$ \\
\hline $\begin{array}{l}15.5 " \\
16.0 " \\
16.5 " \\
17.0 " \\
17.5 " ~\end{array}$ & $\begin{array}{l}0.999 \\
0.999 \\
0.999 \\
0.999 \\
0.999\end{array}$ & $\begin{array}{l}0.999 \\
0.999 \\
0.999 \\
0.999 \\
0.999\end{array}$ & $\begin{array}{l}0.999 \\
0.999 \\
0.999 \\
0.999 \\
0.999\end{array}$ & $\begin{array}{l}0.999 \\
0.999 \\
1.000 \\
1.000 \\
1.000\end{array}$ & $\begin{array}{l}0.999 \\
0.999 \\
1.000 \\
1.000 \\
1.000\end{array}$ & $\begin{array}{l}1.000 \\
1.000 \\
1.000 \\
1.000 \\
1.000\end{array}$ & $\begin{array}{l}1.000 \\
1.000 \\
1.000 \\
1.000 \\
1.000\end{array}$ \\
\hline $\begin{array}{l}18.0 " 1 \\
18.5 " ~ \\
19.0 \\
19.5 " \\
20.0 "\end{array}$ & $\begin{array}{l}9.999 \\
0.999 \\
0.999 \\
1.000 \\
1.000\end{array}$ & $\begin{array}{l}0.999 \\
0.999 \\
0.999 \\
1.000 \\
1.000\end{array}$ & $\begin{array}{l}0.999 \\
1.000 \\
1.000 \\
1.000 \\
1.000\end{array}$ & $\begin{array}{l}1.000 \\
1.000 \\
1.000 \\
1.000 \\
1.000\end{array}$ & $\begin{array}{l}1.000 \\
1.000 \\
1.000 \\
1.000 \\
1.000\end{array}$ & $\begin{array}{l}1.000 \\
1.000 \\
1.000 \\
1.000 \\
1.000\end{array}$ & $\begin{array}{l}1.000 \\
1.000 \\
1.000 \\
1.000 \\
1.000\end{array}$ \\
\hline
\end{tabular}

$$
I_{m \lambda}=I_{0 \lambda} a_{a \lambda}{ }^{m}
$$

と去り，從つて全日射の透過率 $a^{\prime}$ 㳉

$$
\left(a^{\prime}\right)^{m}=\frac{\sum\left(I_{0 \lambda} a_{a \lambda}{ }^{m}\right)}{\sum I_{0 \lambda}}
$$

となる。

先づ $I_{0 \lambda}$ の值として Linke の Meteorologische Taschenbuch に與へられた值を用ひて， $I_{m \lambda} の$ 相對强度を求めれば第 3 圆の如くなる $(\lambda=7 \mu$ 以上性波長のスケールの異ることに注意)，第 3 圆

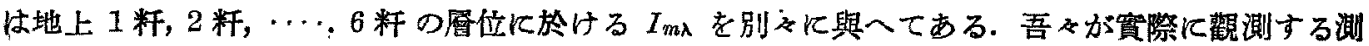
候所は必ずしも常に海面高にあるとは限らず，通常は海找 $H$ 米に在り，又上空に於ける日射のメ ネルギー分布牥畭燥大氣に對してはどのやう庄工合になつて居るかと言ふてとを知り置く必要があ

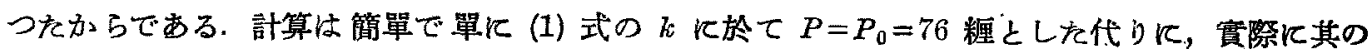

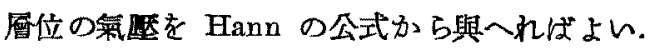

此の圖からかかるととは第 1 Kは地面附近では通過空氣量とよつて $I_{m \lambda}$ ば可成り相違するが，

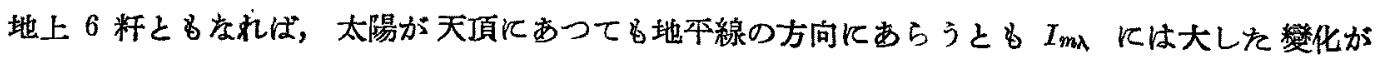

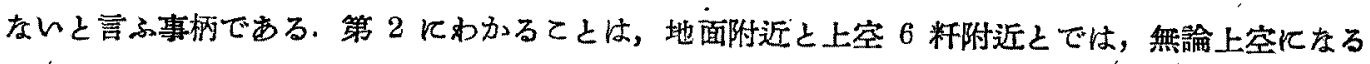

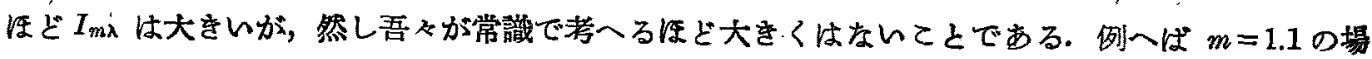
合について言へば地面で $I_{1.1, \lambda=4800 \AA}=53$ で 6 、籸となつても 61 亿すをない. 郎ち其の差は全體の 2

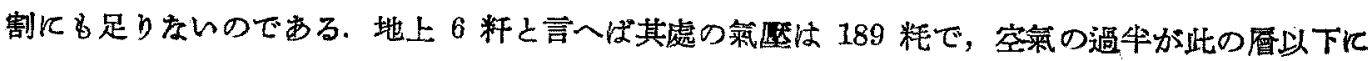
あるに拘らず空茶分子の擴散は 2 割位の違ひがあるだけである。

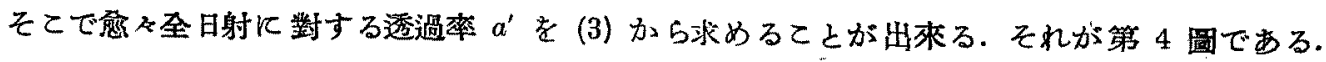

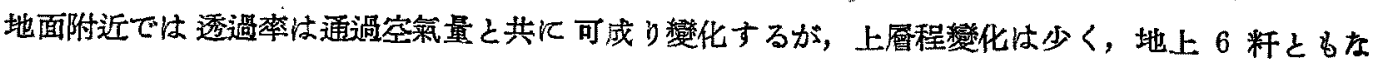
れば太陽が殆んど水平方向で通過空氣量 8 (太陽高度 $7^{\circ}$ ) となつても透過率恃優に 0.9 以上で, 
耗粹大占の城散に就て一一川烟, 川崎
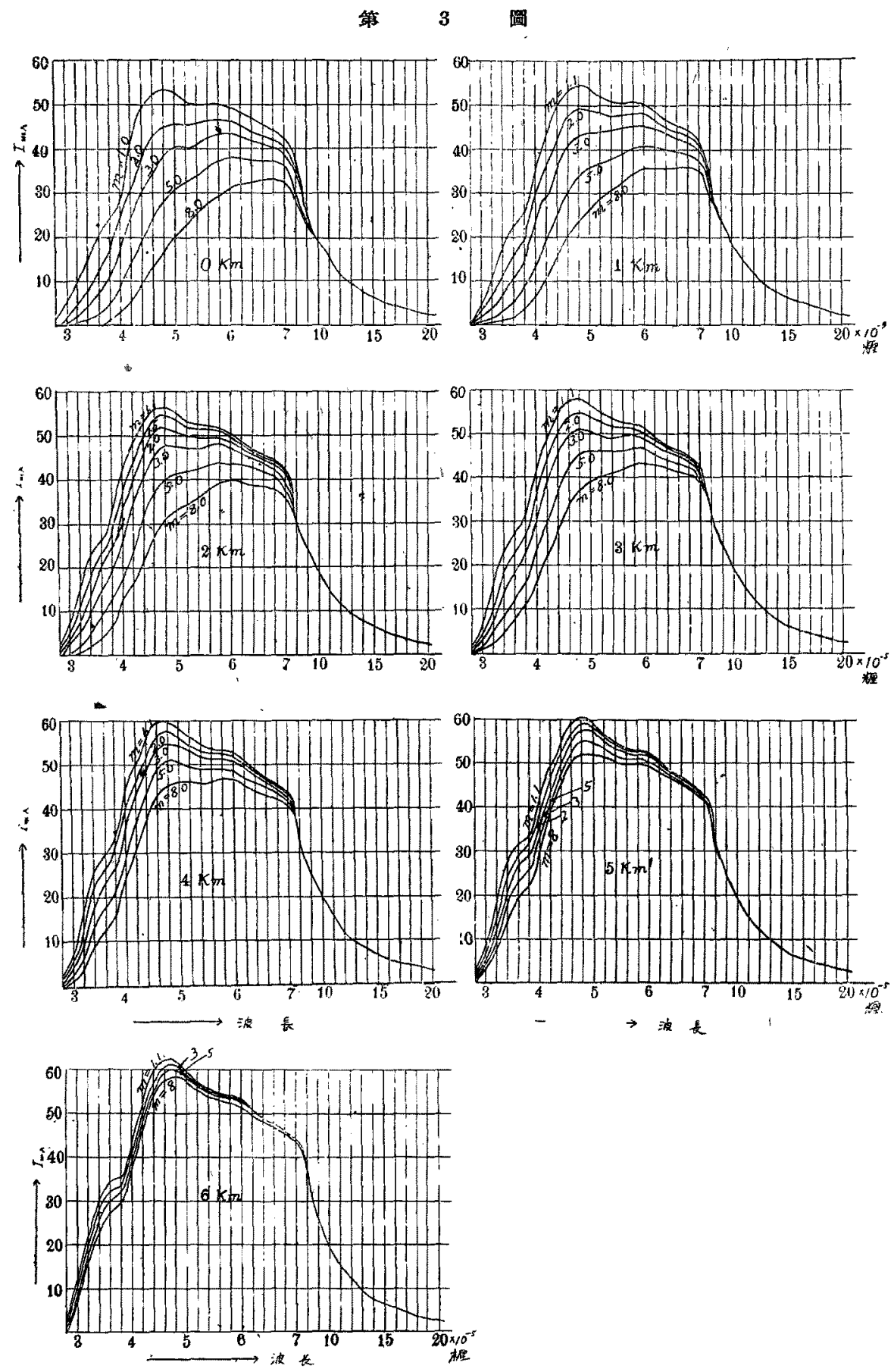
日射は一日中殆んど娍衰するととなく到澾する。

(4)、爇帶地有と溫带地方の比較

以上の計算結果を利用して，純粹乾燥大氣中儿ある空氮分子

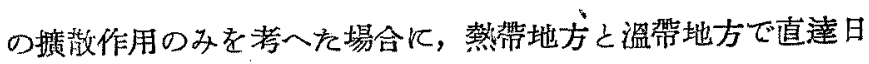
射にどんな相違があるかを調へててみよう。

今太陽の天頂距離を $z$, 特角を $t$ とすれば，一般飞水本面日 射量は $I_{0 \lambda} \cos z$ ‘゙西るから日射日積算量は

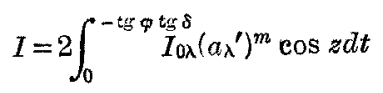

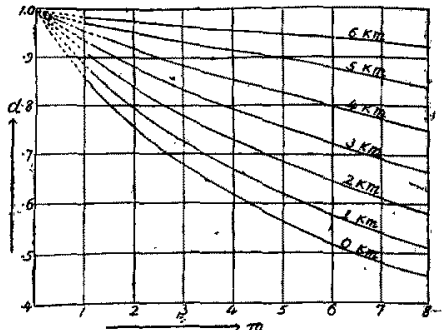

(3)

となる. 但し $\varphi$ は觀測地點の緯度， $\delta$ 法赤緯である。

$$
\cos z=\frac{1}{m}=\sin \varphi \sin \delta+\cos \varphi \cos \delta \cos t
$$

を上式に代用すれば

$$
I=2 \int_{0}^{-\operatorname{tg} \varphi \operatorname{tg} \delta} \frac{1}{m} I_{0 \lambda} a_{\lambda}^{\prime}{ }^{m} d t
$$

今熱帶地方の代表として, 赤道をとり, 溫帶地方の代表として, 稍々南に過をるが緯度 $30^{\circ}$ をと
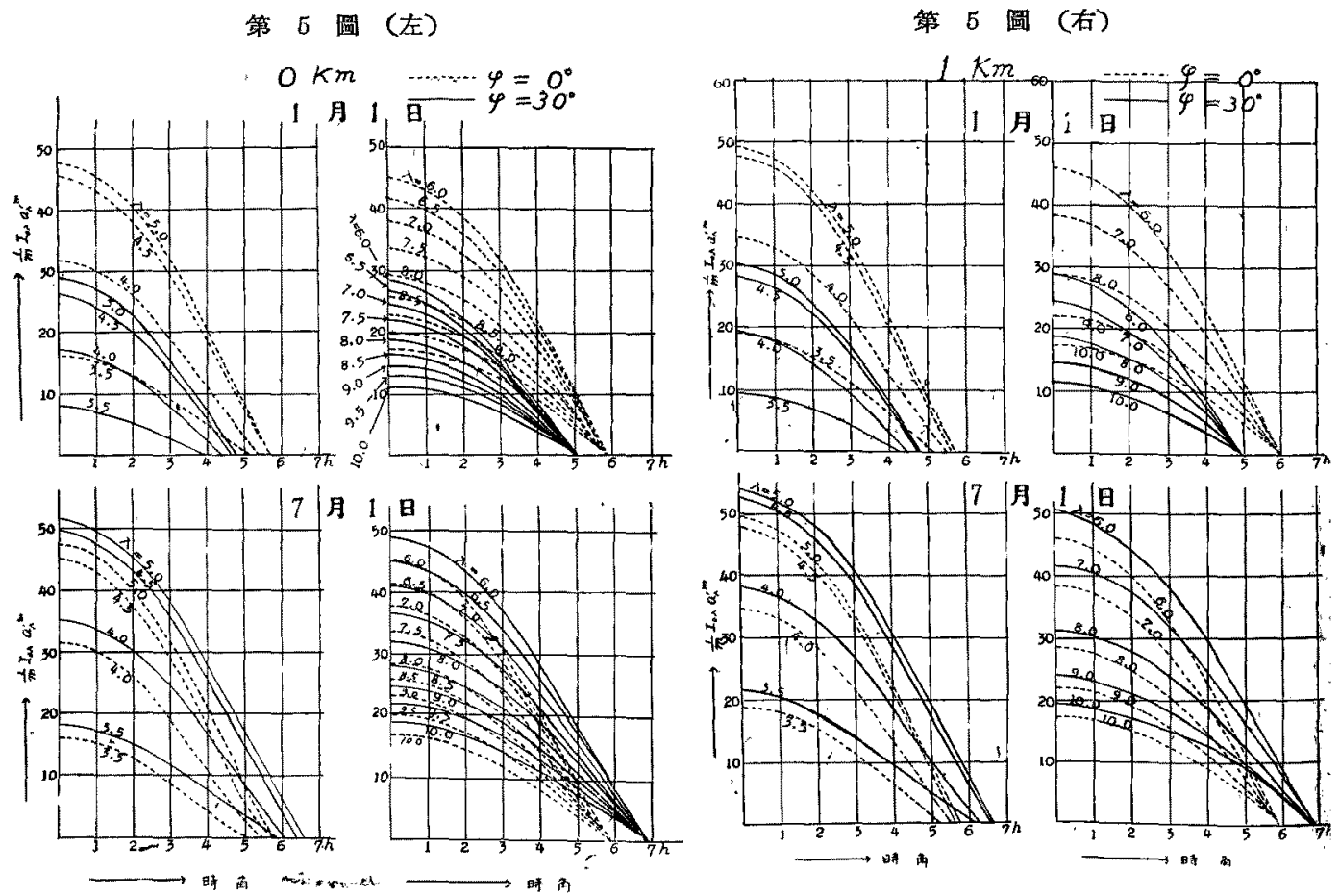
り，更に夏冬の代表として夫ょ 7 月 1 日， 1 月 1 日をとり，(4) 式により $t=0,1,2, \cdots$ の各時

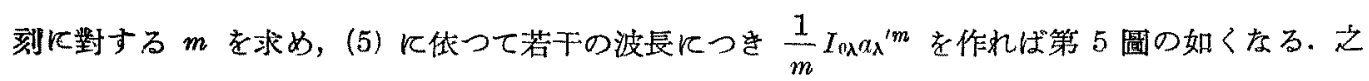
等の曲線之座標軸間の面積牥夫常該波長の輻射量に比例するものでする。それを求めて見ると次 表の如くなる.

第 2 表 緯度 $\varphi=0^{\circ}$ 及び $30^{\circ} \mathrm{N}$ K於ける 1 月 1 日, 7 月 1 日の賞日の波與別日射

$$
\text { (in } 10^{-3} \mathrm{gcal} \cdot \mathrm{cm}^{-2} \cdot \mathrm{min}^{-1} \text { ) }
$$

(純粹大氮の些氣分子の摭散に因る隇衰のみを考慮せる場合)

\begin{tabular}{|c|c|c|c|c|c|c|c|c|c|c|c|c|c|c|c|c|}
\hline & $\begin{array}{c}\lambda= \\
3.5\end{array}$ & $\lambda=$ & $\begin{array}{r}\lambda= \\
4.5 \\
\end{array}$ & $\lambda=$ & $\begin{array}{r}\lambda= \\
4.9 \\
\end{array}$ & $\begin{array}{r}\lambda= \\
5.0\end{array}$ & $\begin{array}{r}\overline{\lambda=} \\
5.5 \\
\end{array}$ & $\begin{array}{r}\lambda= \\
6.0 \\
\end{array}$ & $\begin{array}{r}= \\
6.5 \\
\end{array}$ & $\begin{array}{l}\lambda= \\
7.0 \\
\end{array}$ & $\begin{array}{c}= \\
7.5 \\
\end{array}$ & $\begin{array}{r}\lambda= \\
8.0 \\
\end{array}$ & $\begin{array}{l}\lambda= \\
8.5\end{array}$ & $\begin{array}{r}\lambda= \\
9.0 \\
\end{array}$ & $\begin{array}{l}\lambda= \\
9.5\end{array}$ & $\begin{array}{l}\lambda=10.0 \\
\times 10^{-5} \text { 栍 }\end{array}$ \\
\hline 1月1日 & 12.1 & 25.2 & 38.2 & 40.7 & 42.6 & 41.4 & 40.4 & 41.0 & 37.9 & 35.0 & 31.0 & 26.7 & 24.3 & 20.8 & 18.7 & 16.1 \\
\hline 7 月 1 日 & 12.5 & 25.5 & 37.9 & 40.1 & 40.9 & 41.4 & 39.9 & 40.3 & 38.0 & 35.1 & 31.2 & 26.9 & 23.7 & 20.1 & 19.5 & 15.5 \\
\hline$\varphi=30^{\circ} \mathrm{N}, 1$ 月 1 日 & 4.2 & 11.1 & 18.1 & 19.5 & 20.8 & 21.1 & 21.0 & 21.5 & 20.3 & 19.1 & 16.8 & 14.7 & 13,3 & 11.8 & 10.5 & 8.9 \\
\hline$\varphi=30^{\circ} \mathrm{N}, 7$ 月 1 日 & 15.9 & 31.7 & 48.1 & 50.6 & 50.5 & 50.8 & 50.6 & 50.1 & 46.4 & 431 & 38.5 & 32.5 & 29.9 & 25.1 & 23.4 & 20.2 \\
\hline
\end{tabular}

各種の比弯

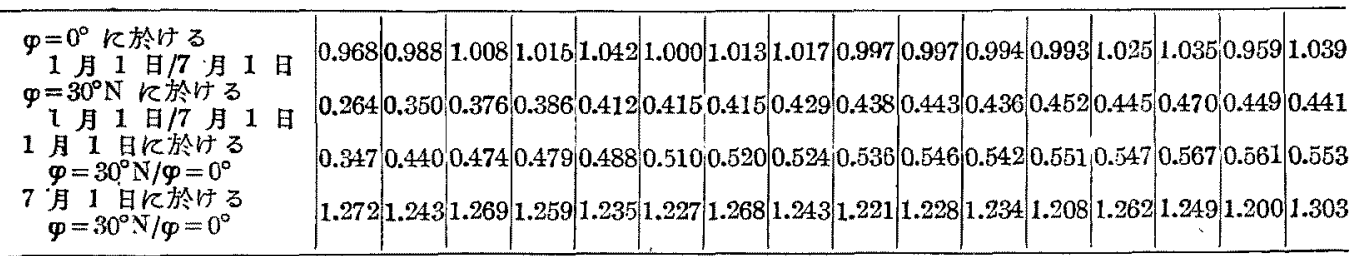

比率表中第 1 行法赤道に於ける冬め日射子夏の日射の割合を示するのであるが，それに上つて 見るに，日射の減衰を單飞純粹空氣分子の搌散飞因るとする限り，一年中變化がをく，其の比殆 んど 1 に近いてとが知られる、之に反して, 北緯 $30^{\circ}$ ともなれば第 2 行より明らかなる如く冬は夏 より著しく小さく，長波長域に於ては冬は夏の約 $45 \%$ 內外，紫外域に於ては $30 \%$ 以下である. 即ち緯度が高くなれば冬の日射は全體として夏の日射よりも小さくなるが，それは紫外線疼ど强く， 例へば $\lambda=3500 \AA$ では $26 \%$ で, 大體赫外域の 2 倍位の減少を示す

第 3 行注冬期に於ける北緯 $30^{\circ}$ と赤道との比を示す 冬期に於ては長波長輻射は大體夏の牛分 强，紫外線は約 $1 / 3$ 位となる. 然るに第 4 行を見るに夏期に於ては寘る北稦 $30^{\circ}$ の日射は赤道よ

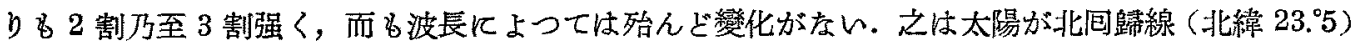
の直上近く，北緯 $30^{\circ}$ の方が赤道より餘計化照射されるためであるが，赤道でも矢張り太陽法直 上飞近い（年中）結果である. 